DOI https://doi.org/10.30525/978-9934-26-073-5-1-37

\title{
МІФОЛОГЕМА ВОДИ В ПОЕЗІЇ АННИ САВРАНСЬКОЇ
}

\author{
Немченко I. B. \\ кандидат філологічних наук, доцент, \\ доцент кафедри української філологї та журналістики \\ Херсонського державного університету \\ м. Херсон, Украӥна
}

Анна-Ванда Гнатівна Савранська (Ковтунович) - сучасна українська поетеса, перекладачка, журналістка, педагогиня, громадська діячка, керівниця літературно-мистецького клубу «Барви» в Корсуні-Шевченківському, що на Черкащині. Вона $\epsilon$ авторкою розмаїтого доробку: це й збірка перекладів із світової класики «І тече твоя душа в мою...» (2016), і книжка оригінальної лірики «Над шумками, над шумочками» (2019), i численні критичні виступи в періодиці. 3 добірками поезій і перекладів, статтями широкого тематичного спектру А. Савранська виступала в багатьох літературно-художніх збірниках, антологіях, альманахах, хрестоматіях («Барви Корсуня», «Росич», «Барви кохання», «Барвисте дитинство», «Барви життя», «Барвінковий цвіт» тощо), у журналах та газетах («Бористен», «Корсунь», «Надросся», «Вісник Корсуня» та ін.), у соціальних мережах.

Про творчу долю мисткині писали В. Метелиця [1], Н. Щербина [5] та інші автори, звертаючи увагу на різні іпостасі іï обдаровання. За словами краянина В. Метелиці, це поетеса «справжня, самобутня, сповнена великих творчих сил, котрі дарувала їй щедра й багата українська земля» [1, с. 5]. Він же підкреслює сугестивний характер іiі лірики: «Читаєш поезії Анни Савранської і хочеться жити, творити, радіти, любити» $[1$, с. 5]. А проте ліричний ужинок цієї авторки лишається малодослідженим. Цим викликана поява нашої розвідки, метою якої $\epsilon$ висвітлення особливостей використання міфологеми води у збірці оригінальної лірики «Над шумками, над шумочками» А. Савранської.

Міфологема води $\epsilon$ наскрізною у книжці поетеси. I це закономірність. Адже глибинною водяною символікою перейнята і світова міфологія, $\mathrm{i}$ фольклор, i художня література. Вода $є$ однією 3 першостихій, невід'ємним елементом світобудови. Як підкреслює Я. Музиченко, одна 3 авторок колективного дослідження «Українські символи», де репрезентує розділ «Вода»: «Нею позначають і пояснюють вічність, космічний простір, межу між світами й станами людського буття, 
а також життєдайне жіноче начало, родючі сили природи, кохання. Тобто вода в уявленні давніх людей виступає Праматір'ю Світу» [2, с.50]. Таке сакралізоване бачення води пропонує й поетеса А. Савранська в своїй книжці лірики.

Поняття вода в інтерпретації авторки має досить широке семантичне поле: басейн, вир, водограй, джерело, дощ, замет, крига, купіль, лід, море, плесо, повінь, потік, річка, роса, сніг, сніжинка, сніговик, струмочок, туман, фонтан, хвиля, хмарка, шумок та ін. Часто ці мікрообрази виступають в текстах як символи, пов'язуючись і з прямим, i $з$ переносним значенням, i з розлогою полісемантичною амплітудою.

Міфологема води в ліричній книжці А. Савранської відзначається багатоаспектністю прочитання, варіативністю інтерпретацій. Відкривається збірка промовистою мініатюрою 3 ключовим мікрообразом чистих джерел, що сприймається як утілення малої батьківщини, батьківської хати на скелі над шумками Росі, дитячої купелі і юнацьких мрій, життєвої снаги, вірності та любові: «Як зернина, закинута в щілину в скелі, / Тут зросла на гранітах, на чистих джерелах, / I сюди несу радість, жалі і покуту, / Мов навіки до теплої скелі прикута» [3, с. 3]. Але ця «прикутість» несе радість, бо освячена любов'ю до рідного куточка, до материнського домашнього вогнища. Тому і рідна скеля «тепла», несе в собі заряд позитивної енергетики.

Наступний стансовий текст ідилічного забарвлення «Тут наче в дитинстві - у раї...» далі розвиває заявлену тему згадкою про «жменьку живої води», натякаючи на цілющий вплив рідної пристані на скитальника по життю. А вірш «Берег дитинства» підсилюе ці незвичайні враження через низку вишуканих мікрообразів: «Зоря-калина здалеку / Відбилася в шумках, / Посипались кришталики / По чистих камінцях; Де скелі зачаровані, / Посивілий граніт, / У незабудках схована / Жива вода бринить» [3, с. 4-5].

Героїня багатьох віршів збірки освідчується в любові до річки дитинства Росі, з якої черпала свою життєву снагу, уявлення про світову красу і велич. Цей водяний простір став невід'ємною часточкою іiі долі: «Річко, річко синьоока, / Подаруй веселу вдачу!» [3, с. 6]; «Моя річко, моя няню, / Мене ждеш біля причалу» [3, с. 7]; «А Рось мене з розуму просто звела; П'янить мене Рось!» [3, с. 9].

Оскільки у десятках віршів збірки йдеться про Рось, до текстів уплітається й історіософський вимір, адже 3 назвою цієї річки пов'язується найменування давніх українців, наші національні витоки, державотворчі процеси тисячолітньої відстані. Тож у поезії «Диво над Россю» - це річка-живинка. Вона живить окрему людину і цілий народ, 
дарує очищення, вселяє віру в себе і націю. Лірична героїня твору вдається до відповідного ритуалу: «Річці магічній / Низько вклонюся» [3, с. 8]. Для неї купання в цій священній річці сприймається як високий обряд очищення і прилучення до чогось величного і вічного: «I я поринаю у світлії води, / Як в давні часи, у загадки природи» [3, с. 10]. Міфологема води інтерпретується в координатах національної та загальнолюдської пам’яті, у нерозривному єднальному ланцюжку між мікрокосмом (людиною) і макрокосмом (усесвітом).

Баркарола «Човен серед річки» фіксує екстатичні відчуття героїв, надиханих присутністю Всевишнього: «Нас двоє у човні посеред неба. / Ми в Бога на долоні - / Слів не треба» [3, с. 16]. Вода освячує стосунки закоханих, ніби нагадує їм: ви творені за Божою подобою. Такий же ідилічно-сакралізований серпанок присутній і в іншій баркаролі «Давня пісня»: «Понад Россю похилились / Віковічні віти. / Тут усі серця зродились / 3 сонця і граніту. // Он ті верби, он той місяць, / Он козак веслує, / І чиясь далека пісня / Все когось хвилює» [3, с. 30].

У цілому ряді віршів збірки вода символізує вірне й жертовне кохання. Це зокрема поезії, що присвячені легендарним героям-корсунчанам із сивої минувшини: закоханій парі - юнакові-полякові Янові та його обраниці-українці Наталці, на перешкоді до щастя яких постали непереборні обставини, що призвели їх до самогубства («Корсунський пам’ятник закоханим», «Янталка», «У Корсунському парку»). Міфологема води увиразнюється мотивом непереможної любові, невичерпного почуття. Річка, яка надала закоханим героям вічний притулок і вічне єднання в смерті, стає їх захисницею перед жорстоким і немилосердним світом. В одній зі своїх статей А. Савранська назвала цю трагічну пару українськими Ромео і Джульєттою [4, с. 3]. Проте поетеса, захоплюючись учинком закоханих, які пішли на смерть, аби не знати розлуки, водночас і не схвалює їх радикального вибору. А може, був ще якийсь шлях, якийсь невикористаний шанс бути щасливими. Тож у рядках авторки мимоволі вчувається й гірка іронія при спогляданні пари, навічно завмерлої у вигляді пам'ятника: «Ян з Наталкою, як раніше, / Видивляються, де б втопитись» [3, с. 38].

Розділ збірки «Древня Рось - зарегульована ріка» відкривається щемливою поезією «Річка плачу». Твір задає тон усій тематичній добірці екологічної проблематики. Риторичне питання «Річко, річко плачу i суму, / Де твоя історична слава?» [3, с. 45 ] переадресовується тим, хто давно й цілеспрямовано нищить цю водоносну артерію заради своїх прибутків та власної втіхи. Вірші «Ріка доживає», «Люби цю річку», «Вода - жива», «Зарегульована ріка», «Проєкт» варіюють цей болючий 
мотив, до якого додаються ще й трагічні нотки Чорнобильського лиха. Рось, яка стала символом стародавності й самобутності українського світу, вироджується, гине на очах ситості й байдужості. Бо не лише «зажерливий лихий олігархат» несе відповідальність за такий фатальний стан речей. Винне все суспільство, що не береже свої святині. Як глас вопіющого в пустелі, звучить заклик поетеси: «Вода... Поглянь, вона жива - / У ній і код, і пам'ять, в ній історія. / Допоки варить голова, / Люби цю воду, річку - вічну, зоряну!» [3, с.48]. Але, певно, голова у багатьох давно вже не «варить».

Мотив живої/мертвої води, що прийшов з міфічних праглибин, у авторки набуває нових відтінків і нюансів. Йдеться вже до того, що не буде ні однієї, ні іншої. Ретранслюється ефект зникомості. Вода ще $\epsilon, \mathrm{i}$ вже іiі нема: «Вже ледь живе... I все одно жива!» [3, с. 49]. Поетеса вдається і до трагічної патетики голосіння: «Річко, річко, а тобі ж мільйони літ! / I невже ти полишаєш білий світ?» [3, с. 50], і до апокаліптичних передбачень: «Скоро підемо ми пішки через Рось» $[3$, c. 50], натякаючи на невигойну духовну мілину співвітчизників, що $\epsilon$ загрозою буття самої нації. Звідси болючі апеляції до побратимів по перу, до майстрів пензля: «Митці, малюйте все, будь-ласка, / I річку, й поки $\epsilon$ - шумки...» [3, с. 52].

Звертаючись до міфологеми води, А. Савранська мобілізує і власні творчі ресурси, і потенціал своїх реципіснтів у напрямку очищення, духовного відродження, інтелектуального піднесення в околі на противагу процесам самоїдства, виродження, девальвації одвічних цінностей. Безперечною $є$ сугестивна сила віршів письменниці, яка i в найтяжчі часи випромінює оптимізм, віру і любов.

\section{Література:}

1. Метелиця Володимир. Любов - то натхнення Анни Савранської. Надросся. 2019. 17 січня. С. 5.

2. Музиченко Ярослава. Вода. Дмитренко М., Іваннікова Л., Лозко Г. та ін. Украӥнські символи. К.: Редакція часопису «Народознавство», 1994. C. 50-58.

3. Савранська Анна. Над шумками, над шумочками: вірші. Корсунь-Шевченківський: ФОП Майдаченко І. В., 2019. 56 с.

4. Савранська Анна. Пам'ятник українським Ромео і Джульєтті. Корсунь. 2013. 20 вересня. С. 3.

5. Щербина Надія. 3 нею просто i цікаво. Корсунь. 2007. 1 червня. С. 2. 